\title{
KESESUAIAN POLA KEMEJA PRIA SISTEM ALDRICH TERHADAP PRIA BERTUBUH IDEAL INDONESIA
}

\author{
Rosi Rizki Fadillah ${ }^{1^{*}}$, Adriani $^{2^{*}}$ \\ Program Studi Pendidikan Kesejahteraan Keluarga Jurusan Ilmu Kesejahteraan Keluarga \\ Fakultas Pariwisata dan Perhotelan \\ Universitas Negeri Padang \\ Jl. Prof. Dr. Hamta, Air Tawar Padang, Kel. Air Tawar Barat, Kec. Padang Utara, Kota Padang, Kode Pos 25171 \\ Sumatera Barat. Indonesia \\ Email: fadillahrosirizki@gmail.com
}

\begin{abstract}
Abstrak
Tujuan penelitian untuk mendeskripsikan kelemahan, cara memperbaiki, serta kesesuaian pola kemeja pria sistem Aldrich terhadap pria bertubuh ideal Indonesia. Metode penelitian menggunakan penelitian terapan. Teknik analisa data menggunakan statistik deskriptif berupa perhitungan rumus persentase menggunakan microsoft excel. Objek penelitian yaitu pola kemeja pria sistem Aldrich yang diuji cobakan pada pria bertubuh ideal Indonesia, dengan tinggi $170 \mathrm{~cm}$, berat $63 \mathrm{~kg}$. Dinilai oleh 5 orang panelis yang ahli dibidang pola busana pria. Instrumen penelitian yang digunakan adalah kuesioner/angket memakai skala likerts. Hasil penelitian menunjukkan bahwa pola kemeja pria sistem Aldrich terhadap pria bertubuh ideal Indonesia, mempunyai 5 kelemahan berdasarkan penilaian dari 5 orang panelis diantaranya yaitu: 1) lingkar dada berlebih $3 \mathrm{~cm}, 2$ ) lebar punggung berlebih $2,5 \mathrm{~cm}, 3$ ) panjang kemeja kurang $5 \mathrm{~cm}, 4$ ) lingkar kerung lengan berlebih 2,5 cm, 5) lingkar ujung lengan berlebih 2,5 cm. Cara memperbaikinya yaitu: 1) lingkar dada dikurangi $3 \mathrm{~cm}$ pada sisi kiri dan kanan, 2) lebar punggung dikurangi $2,5 \mathrm{~cm}$ pada sisi kiri dan kanan, 3) panjang kemeja ditambah $5 \mathrm{~cm}, 4$ ) lingkar kerung lengan dikurangi $2,5 \mathrm{~cm}, 5$ ) lingkar ujung lengan dikurangi $2,5 \mathrm{~cm}$. Kesesuaian didapat dengan mencocokkan hasil dari kelemahan dan cara perbaikan pola kemeja pria sistem Aldrich terhadap pria bertubuh ideal Indonesia.
\end{abstract}

Kata Kunci: kesesuaian, kemeja, aldrich, pria ideal.

\begin{abstract}
The purpose of this study is to describe the weaknesses, how to improve, and the suitability of Aldrich's men's shirt pattern towards ideal Indonesian male posture. The method uses applied study. The data analysis was performed using descriptive statistics in the form of calculating formula percentages using Microsoft Excel. The object of this study was the Aldrich's men shirt pattern which were tested on an ideal Indonesian male posture, with a height of $170 \mathrm{~cm}$, weight of $63 \mathrm{~kg}$. Judged by 5 panelists who are experts in men's clothing. The study instrument was a questionnaire / questionnaire using the Likerts scale. The results showed that the Aldrich's men shirt pattern towards an ideal Indonesian male posture had 5 weaknesses based on the assessment from 5 panelists which were : 1) chest circumference over 3 $\mathrm{cm}, 2)$ back width over $2.5 \mathrm{~cm}, 3)$ shirt length less $5 \mathrm{~cm}, 4)$ sleeve circumference over $2.5 \mathrm{~cm}$, 5) arm tip circumference over $2.5 \mathrm{~cm}$. How to improve it are: 1) chest circumference shortened by $3 \mathrm{~cm}$ on the left and right side, 2) Back width shortened by $2.5 \mathrm{~cm}$ on the left and right side, 3) Shirt length extended by $5 \mathrm{~cm}$, 4) Sleeve circumference shortened by $2.5 \mathrm{~cm}$, 5) arm tip circumference shortened by $2.5 \mathrm{~cm}$. The suitability is obtained by matching the results of the weaknesses and how to improve Aldrich's men shirt pattern towards ideal Indonesian male posture.
\end{abstract}

Keywords: suitability, shirt, aldrich, ideal man.

\section{PENDAHULUAN}

Kemeja merupakan salah satu busana bagian atas untuk pria. Dalam bahasa Inggris kemeja adalah pakaian khusus yang terdiri dari kerah, lengan dan manset, serta terdapat kancing pada belahan tengah muka. Kemeja untuk pria mempunyai bentuk kerah standar (krah dengan ban penegak), lengan baju panjang dengan manset, dan bentuk modelnya yang sangat variatif. Definisi kemeja menurut Poespo (2005:13) yang menyatakan bahwa kemeja merupakan pakaian dasar klasik dari segala model.

Kemeja merupakan salah satu materi yang terdapat pada mata kuliah busana pria di jurusan Ilmu 
Kesejahteraan Keluarga (IKK), Fakultas Pariwisata dan Perhotelan (FPP), Universitas Negeri Padang (UNP). Berdasarkan hasil wawancara peneliti dengan salah seorang dosen yang mengajar busana pria berinisial "T", bahwa pola yang biasa dipakai dalam mata kuliah busana pria yaitu pola hasil dari pelatihan dosen. Hal ini dikarenakan tidak adanya referensi terkait atau penelitian sebelumnya tentang pola-pola yang berasal dari beberapa sistem, diantaranya pola kemeja pria sistem Aldrich. Pola kemeja sistem Aldrich berasal dari Inggris. Diciptakan oleh Winifred Aldrich pada buku Metric Pattern Cutting For Menswear. Terdapat beberapa keunggulan dari pola sistem Aldrich, diantaranya dari segi panduan mengambil ukuran tubuh yang mudah untuk dipahami, jumlah ukuran bada yang tidak terlalu banyak, dan langkah pembuatan pola yang mudah untuk dimengerti.

Ditinjau dari segi ukuran, terdapat beberapa perbedaan dengan sistem pola yang lainnya. Ada 8 ukuran yang diperlukan dalam pembuatan kemeja pria sistem Aldrich, diantaranya : ukuran panjang punggung, panjang pakaian, lingkar leher, setengah lebar punggung yang diambil dari ukuran penuh lebar punggung kemudian dibagi dua, lingkar dada dengan cara menempatkan pita ukuran disekeliling lingkar dada dan melewati tulang belikat, tinggi ketiak yang didapat dari garis tulang leher bawah sampai kebagian garis ketiak, panjang lengan, lingkar manset (Aldrich, 2015:156).

Sistem pola lain, seperti sistem pola Soekarno ukuran yang digunakan diantaranya, lingkar badan, lingkar pinggung, lingkar leher, panjang lengan, 1/2 lingkar lengan, rendah bahu, rendah punggung, panjang punggung (Soekarno, 2016:19).

Terdapat beberapa perbedaan dari segi ukuran tubuh antara pria Inggris dan pria Indonesia. Untuk tinggi rata-rata pria di Inggris adalah sekitar $178 \mathrm{~cm}$. Menurut Aldrich (2015:5) ukuran rata-rata pria Inggris seperti : 1) lingkar dada 96-100 cm, 2) rata-rata lingkar pinggang 94-101.

Sedangkan tinggi tubuh pria di Indonesia rata-rata 165,68 cm (Djaja Surya, 2013:5). Menurut Soekarno (2009:17) ukuran rata-rata pria Indonesia seperti: 1) lingkar pinggang $78-80 \mathrm{~cm}, 2$ ) lingkar dada $92-95 \mathrm{~cm}$.

Berdasarkan penjelasan diatas dapat dilihat bahwa antara pria Inggris dan Indonesia memiliki beberapa perbedaan dari segi ukuran tubuh. Maka, dengan adanya perbedaan tubuh antara pria Inggris dan
Gorga Jurnal Seni Rupa

Volume 08 Nomor 01 Januari-Juni 2019

p-ISSN: 2301-5942 | e-ISSN: 2580-2380

Indonesia perlu dilakukan penelitian secara sistematis untuk mendapatkan bentuk berat badan ideal. Berat badan ideal merupakan suatu kondisi berat badan yang seimbang dengan tinggi badan yang dimiliki. Sehingga didapatkan penampilan fisik yang tampak ideal, yaitu tidak terlalu kurus dan tidak terlalu gemuk. Pada umumnya untuk mengetahui berat badan ideal, seseorang harus terlebih dahulu menimbang berat badan dan mengukur tinggi badannya. Kemudian setelah itu melakukan perhitungan dengan rumus matematis tertentu, sehingga diperoleh suatu kesimpulan tentang kondisi berat badan idealnya (Toni, 2017: 8). Menurut Pratiwi (2001:6) mengatakan "bentuk tubuh manusia digolongkan menjadi lima macam bentuk tubuh yaitu normal, atau ideal, gemuk pendek, kurus pendek, tinggi gemuk dan tinggi kurus".

Untuk menentukan berat badan ideal, maka rumus yang digunakan adalah metode Brocca (2008:79), dimana berat badan ideal $=($ Tinggi badan-100 $)-$ $10 \%$ (Tinggi badan-100). Batas ambang yang diperbolehkan adalah $\pm 10 \%$ dari berat badan ideal. Bila berat badan $<90 \%$ (kurus), $>10 \%$ (gemuk), $>20 \%$ (obesitas). Jadi, dari rumus tersebut dapat diketahui bahwasanya seseorang pria Indonesia yang memiliki tinggi badan $170 \mathrm{~cm}$, berat badan $63 \mathrm{~kg}$. Maka, berat badan ideal $=(170 \mathrm{~cm}-100)-10 \%(170 \mathrm{~cm}-100)=$ $70 \mathrm{~cm}-7 \mathrm{~cm}=63 \mathrm{~kg}$.

Kategori bentuk badan menurut Thomas (2018:5) a) Kurus $(\mathrm{BB}<59 \mathrm{~kg}, \mathrm{~TB}<159 \mathrm{~cm})$, b) normal/ideal (BB 59-69 kg, TB 159-173 cm), c) gemuk (BB 75-81 $\mathrm{kg}$, TB $171 \mathrm{~cm}$ ), d) gemuk sekali (BB $<82 \mathrm{~kg}$, TB 165 $\mathrm{cm})$. Untuk mendapatkan pola kemeja pria yang sesuai dengan bentuk tubuh perlu dilakukan fitting. menurut Yasnidawati (2012:84) “Fitting adalah menyesuaikan atau pengepasan suatu pakaian pada tubuh seseorang agar pakaian tersebut pas dan benarbenar tepat dengan ukuran dan bentuk tubuh sipemakai”. Fitting menunjukkan pada sempit dan longgarnya sebuah bentuk busana dalam hubungannya dengan orang yang memakainya.

Setelah melakukan fitting barulah didapat kesesuaian pola kemeja pria sistem Aldrich terhadap pria bertubuh ideal. Menurut Menurut Alwi (2007:109) "Kesesuaian adalah kecocokan, keselarasan". Pola kemeja pria sistem Aldrich di sesuaikan dengan tubuh pria ideal Indonesia.

Tujuan dari penelitian ini adalah mendeskripsikan beberapa hal sebagai berikut : 
1. Kelemahan yang terdapat pada pola kemeja sistem Aldrich untuk pria bertubuh ideal di Indonesia.

2. Cara memperbaiki pola kemeja sistem Aldrich untuk pria bertubuh ideal di Indonesia.

3. Hasil pola kemeja sistem Aldrich yang sudah disesuaikan untuk pria bertubuh ideal di Indonesia.

\section{KAJIAN TEORI}

\section{Kemeja Sistem Aldrich}

Kemeja dari bahasa Portugis disebut camisa. Camisa adalah sebuah baju atau pakaian atas, terutama untuk pria. Pakaian ini menutupi tangan, bahu, dada sampai ke perut. Pada umumnya berkerah dan berkancing depan, terbuat dari katun, linen. Menurut Wening (2013:16) "Kemeja merupakan dasar klasik dari segala model. Kemeja untuk pria mempunyai bentuk kerah standar yaitu kerah dengan penegaknya, lengan panjang dengan manset”.

Model kemeja untuk busana pria berbeda dengan model blus/gaun untuk busana wanita atau anak wanita. Model kemeja pria selalu terlihat sederhana dari tahun ketahun. Sedangkan busana wanita lebih fleksibel dan luwes dengan model yang setiap waktu berubah. Perbedaan ini disebabkan karena postur tubuh wanita berbeda dengan postur tubuh pria sehingga akan mempengaruhi model pakaian yang dikenakan. Tingkat kesulitan kemeja lengan panjang terletak pada hasil kerah dan manset.

Winifred Aldrich adalah seorang perancang busana yang berpengalaman di bidang industri dan pendidikan. Aldrich bekerja sebagai seorang dosen di Loughborough dan London selama 14 tahun dan melanjutkan penelitiannya di Nottingham Trent University.

Pola kemeja Aldrich terdiri atas pola badan depan dan belakang kemeja, pola lengan, pola kerah, dan pola manset. Untuk mendapatkan pola kemeja yang sesuai dengan bentuk tubuh dilakukan beberapa tahapan dalam pembuatanya, yaitu sebagai berikut : 1) Alat dan bahan dalam pembuatan pola (pita ukuran, kapur jahit, gunting, penghapus, jarum, pensil, kertas pola, penggaris), 2) mengambil ukuran badan (panjang punggung, lingkar dada, 1/2 lebar punggung, panjang baju, panjang lengan, lingkar leher, lebar manset).

Pembuatan pola kemeja sistem Aldrich mengikuti langkah-langkah panduan sesuai dengan sistem Aldrich. Pembuatan pola dimulai dari pengambilan ukuran, persiapan alat-alat pembuatan pola, dan proses-proses pembuatan pola.
Gorga Jurnal Seni Rupa

Volume 08 Nomor 01 Januari-Juni 2019

p-ISSN: 2301-5942 | e-ISSN: 2580-2380

\section{Bentuk Tubuh Pria Ideal}

Ukuran tubuh memiliki peranan yang penting dalam pembuatan busana. Setiap orang mempunyai ukuran tubuh yang berbeda-beda, hal ini juga disebabkan perkembangan fisik, jenis kelamin, usia, dan perkembangan biologisnya. Menurut Poespo (2000:40) " desain badan kita ditentukan oleh faktor keturunan (genetik) dan pengaruh makanan serta lingkungan hidup kita".

Bentuk dan ukuran tubuh adalah gambaran atau keseluruhan jasad manusia yang kelihatan dari ujung rambut sampai ujung kaki". Perbedaan bentuk tubuh pada manusia dipengaruhi oleh beberapa faktor, seperti keadaan fisik, perbedaan jenis kelamin, faktor biologis, dan lain-lain. Bentuk tubuh manusia dapat digolongkan berdasarkan kategori tertentu.

Untuk mendapatkan ukuran tubuh pria ideal maka diperlukan rumus yang sesuai. Rumus yang digunakan untuk mengetahui berat badan ideal adalah rumus dengan metode Brocca, seperti yang dikemukakan oleh Thomas (2008:79), sebagai berikut :

Berat badan ideal $=($ Tinggi badan -100$)-10 \%($ Tinggi badan-100)

Keterangan:

Batas ambang yang diperbolehkan adalah $\pm 10 \%$ a dari berat badan ideal

a.Apabila $<90 \%$ dikatakan kurus

b.Apabila $>10 \%$ termasuk gemuk

c.Apabila $>20 \%$ termasuk obesitas

\section{Kesesuaian Pola}

Pola yang sudah pas pada badan seseorang, maka dapat dikatakan bahwa pola tersebut sudah sesuai atau cocok dengan bentuk tubuhnya. Menurut Alwi (2007:109) "Kesesuaian adalah kecocokan, keselarasan". Pola kemeja sistem Aldrich di sesuaikan dengan tubuh pria ideal Indonesia. Untuk melihat kesesuaian pola maka dilakukan fitting beberapa kali untuk mendapatkan hasil yang pas. Fitting menunjukkan pada sempit dan longgarnya sebuah bentuk busana dalam hubungannya dengan orang yang memakainya. Busana yang enak dipakai adalah yang berukuran tepat dan tidak menyesakkan ataupun kedodoran/longgar bila dikenakan (Poespo 2000:72).

fitting memiliki peranan penting untuk melihat kesesuain pola yang dibuat dengan hasil jadi pola pada bahan yang sudah dijahit pada tubuh seseorang. Tujuan fitting dalam pembuatan busana adalah: mengetahui hasil pola pakaian, melihat kekurangan 


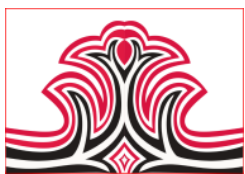

pola pakaian, supaya hasil benar-benar tepat sesuai bentuk tubuh sipemakai.

\section{METODE PENELITIAN}

Penelitian ini tergolong penelitian terapan. Penelitian ini bersifat praktis, diperlukan dalam rangka perbaikan atau penyempurnaan suatu produk atau proses tertentu, dengan menguji suatu konsep teoritis tertentu di dalam menghadapi masalah nyata pada situasi tertentu.

Dalam pembuatan pola kemeja dilakukan analisa terhadap kekurangan dan kelebihanya sehingga terbentuk suatu pola yang sesuai dan dapat diaplikasikan untuk pria bertubuh ideal di Indonesia.

penelitian ini terdiri dari satu variabel yaitu: "Kesesuaian pola kemeja sistem Aldrich terhadap pria bertubuh ideal Indonesia", dengan indikator sebagai berikut: (Pola kerah, Pola badan, Pola lengan, Pola manset).

Objek penelitian adalah pola kemeja Sistem Aldrich yang disesuaikan pada pria bertubuh ideal. Diujicobakan pada pria yang bertubuh ideal berusia 22 tahun, dengan tinggi badan $170 \mathrm{~cm}$ dan berat badan $63 \mathrm{~kg}$

Instrumen yang digunakan dalam penelitian ini adalah kuesioner atau angket. Menurut Sugiyono (2009:199) "kuesioner merupakan teknik pengumpulan data yang dilakukan dengan cara memberi seperangkat pertanyaan atau penyataan tertulis kepada responden untuk dijawabnya".

Skala yang digunakan berupa skala Likerts. Menurut Sugiyono (2009:135) "Skala Likerts adalah jawaban setiap item instrumen yang menggunakan skala Likerts mempunyai gardisi dari sangat positif sampai sangatnegatif'. Instrumen pada penelitian ini berisikan 4 pilihan jawaban, yaitu: Sangat sesuai (SS) dengan skor 4, Sesuai (S) dengan skor 3, Kurang Sesuai (KS) dengan skor 2, Tidak Sesuai (TS) dengan skor 1.Untuk melakukan uji coba instrumen, menggunakan validitas logis dan validitas konstruk. Sedangkan kontrol validasi dilakukan dengan menggunakan bahan wol, pengambilan ukuran disesuaikan dengan sistem pola, setiap langkah pola dicek ketepatan ukuran, penilaian dilakukan dengan cara uji coba pola kemeja pria terhadap pria bertubuh ideal Indonesia. Penilaian dilakukan oleh 5 orang panelis yang ahli dalam bidang pola busana pria. Pada setiap item yang sudah sangat sesuai (skor 4), penilaian tidak perlu dilakukan untuk fitting selanjutnya.
Gorga Jurnal Seni Rupa

Volume 08 Nomor 01 Januari-Juni 2019

p-ISSN: 2301-5942 | e-ISSN: 2580-2380

Teknik analisa data yang digunakan analisa statistik deskriptif. Menurut Arikunto (2010:227) mengatakan bahwa "statistik deskriptif merupakan statistik yang bertugas untuk mendeskripsikan atau memaparkan gejala hasil penelitian".

Dalam penelitian ini menggunakan perhitungan rumus persentase :

$$
\mathrm{P}=\frac{f}{N} \times 100 \%
$$

Keterangan:

$\mathrm{P}=$ Persentase

$\mathrm{F}=$ Jumlah skor dari panelis

$\mathrm{N}=$ Jumlah banyak skor

Data diolah menggunakan Microsoft Excel, hasil yang diperoleh dikelompokkan dalam 5 kategori standar penilaian yang dikemukakan oleh Arikunto (2010:44) yaitu:

$81 \%-100 \%=$ Sangat Tinggi

$61 \%-80 \%=$ Tinggi

$41 \%-60 \%=$ Sedang

$21 \%-40 \%=$ Rendah

$0 \%-20 \%=$ Sangat rendah

\section{HASIL DAN PEMBAHASAN \\ 1.Hasil}

Berdasarkan hasil analisis data yang telah dilakukan maka terdapat beberapa kelemahan pada pola kemeja pria sistem Aldrich terhadap pria bertubuh ideal Indonesia.

Kelemahan pola kemeja pria sistem Aldrich, diantaranya :

1).Lingkar dada dengan hasil penilaian (modus 2 , median 2, dan persentase 55\%). Item ini dinilai kurang sesuai, karena terdapat penambahan sebsesar $8 \mathrm{~cm}$ pada rumus $1 / 2$ lingkar dada $+8 \mathrm{~cm}$. Sehingga menyebabkan kemeja menjadi kebesaran.

2). Lebar punggung dengan hasil penilaian (modus 2 , median 2, dan persentase 40\%), lebar punggung berlebih karena ada penambahan $2,5 \mathrm{~cm}$ pada rumus lebar punggung, sehingga garis bahu tidak tepat pada ujung bahu atau jatuh $3 \mathrm{~cm}$ dari garis ujung bahu.

3 ). Panjang kemeja dengan hasil penilaian (modus 2 , median 2 dan persentase 50\%), panjang kemeja kurang sehingga baju terlihat kurang sesuai dengan model.

4).Lingkar kerung lengan dengan hasil penilaian (modus 3, median 3, dan persentase 65\%), Lingkar kerung lengan kebesaran karena pengaruh dari lingkar dada.

5).Lingkar ujung lengan dengan hasil penilaian (modus 3, median 3, dan persentase 65\%), lingkar ujung lengan besar $1,5 \mathrm{~cm}$ pada sisi kiri dan kanan karena mengikuti garis kerung lengan yang berlebih. 


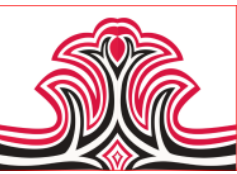

Cara memperbaiki pola kemeja pria sistem Aldrich adalah dengan cara penyesuaian. Penyesuaian pola dilakukan dengan menggunakan tanda pola. Tanda pola yang digunakan dalam memperbaiki pola sesuai dengan pendapat Ernawati (2008:249) yaitu memperbesar pola dengan tanda ////// mengecilkan pola ditandai dengan xxxxxx. Berikut adalah cara penyesuaian pola kemeja pria sistem Aldrich setelah fitting 1, memperbaiki pola sesuai kelemahan diatas dengan cara sebagai berikut:

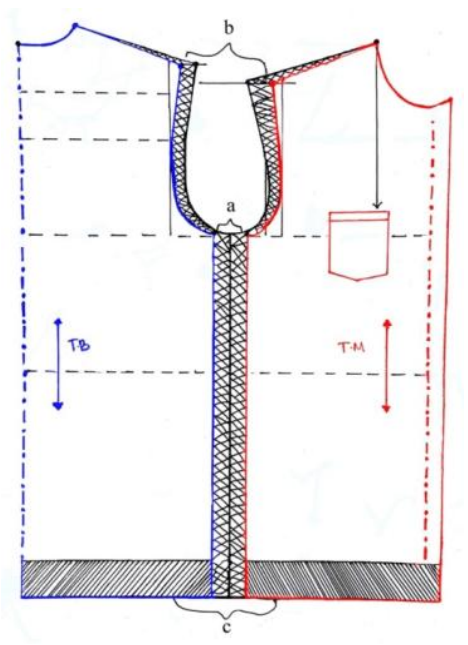

Gambar 1. Hasil Penyesuaian Pola Badan. (Sumber: Rosi Rizki Fadillah, 2018)

(1) Lingkar dada (Dari hasil penilaian panelis cara memperbaiki lingkar dada yaitu dengan mengurangi sisi sebesar $3 \mathrm{~cm}$ pada bagian pola depan dan belakang), (2) Lebar punggung (Dari hasil penilaian panelis maka lebar punggung perlu diperbaiki dengan cara mengurangi ukuran penambahan sebesar $2,5 \mathrm{~cm}$ ), (3) Panjang kemeja (Dengan hasil penilaian panelis panjang kemeja kurang sehingga baju terlihat kurang sesuai dengan model. Dengan demikian panjang kemeja perlu ditambah sebesar $4-5 \mathrm{~cm}$ ).
Gorga Jurnal Seni Rupa

Volume 08 Nomor 01 Januari-Juni 2019

p-ISSN: 2301-5942 | e-ISSN: 2580-2380

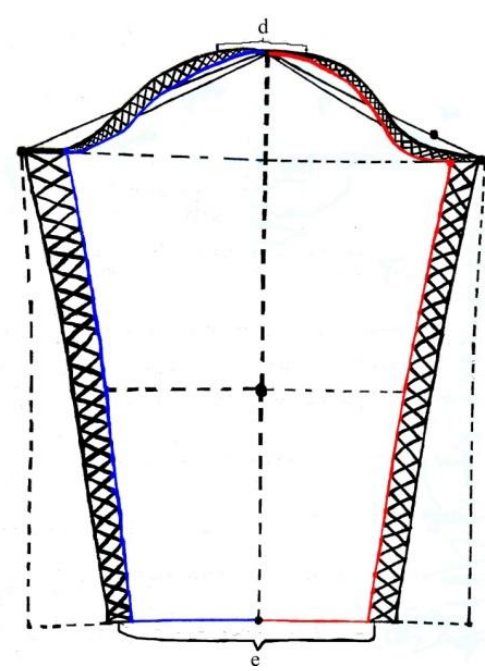

Gambar 2. Hasil Penyesuaian Pola Lengan. (Sumber: Rosi Rizki Fadillah, 2018)

\section{(1) Lingkar kerung lengan (Dengan}

hasil penilaian panelis lingkar kerung lengan terlihat besar karena pengaruh dari lingkar kerung lengan dibadan, sehingga kerung lengan perlu dikurangi dan disesuaikan dengan lingkar kerung lengan yang ada di pola badan), (2) Lingkar ujung lengan (Dengan hasil penilaian panelis, lingkar ujung lengan berlebih, hal ini dikarenakan mengikuti ukuran kerung lengan. Sehingga ukuran lingkar ujung lengan dikurangi 2,5 $\mathrm{cm}$.

Dari uraian diatas dapat dilihat bahwa pola kemeja sistem Aldrich pada fitting 1 berdasarkan modus, median, dan persentase, terdapat beberapa kelemahan sebanyak 5 item yaitu lingkar dada, lebar punggung, panjang kemeja, lingkar kerung lengan, dan lingkar ujung lengan. Kesesuaian pola kemeja sistem Aldrich terdapat pada fitting II, karena semua item berdasarkan modus, median, dan persentase dinilai sangat sesuai oleh para panelis. Jadi, berdasarkan penilaian pada fitting II pola kemeja sistem Aldrich di golongkan kedalam kategori sangat tinggi dan dapat digunakan pada pria bertubuh ideal di Indonesia.

\section{Pembahasan}

Hasil penelitian ini akan mendeskripsikan kelemahan, cara memperbaiki, dan kesesuaian pola kemeja pria sistem Aldrich. Berdasarkan hasil penelitian ditemukan 5 kelemahan pola kemeja pria sistem Aldrich terhadap pria bertubuh ideal Indonesia pada fitting 1. Untuk penyesuaian pola kemeja pria sistem Aldrich terhadap pria bertubuh ideal Indonesia membutuhkan 2 (dua) kali fitting sehingga pola kemeja pria bisa dipakai untuk pria bertubuh ideal Indonesia. 


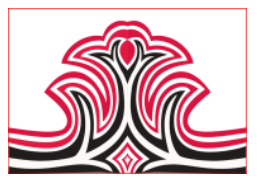

Cara memperbaiki pola kemeja pria sistem Aldrich. Berdasarkan hasil analisis penilaian pola kemeja pria sistem Aldrich pada pria bertubuh ideal Indonesia dengan median 3, modus 3, dan persentase

$71 \%$. Berdasarkan hasil tersebut pola kemeja pria dikategorikan sesuai untuk pria bertubuh ideal Indonesia, tetapi masih terdapat 5 dari 15 item yang dinilai kurang sesuai oleh panelis, oleh sebab itu pola kemeja pria harus diperbaiki.

Penyesuaian pola kemeja pria sistem Aldrich pada pria bertubuh ideal Indonesia dilakukan dengan perbaikan pada proses membuat pola badan yaitu ( lingkar badan, lebar punggung, dan panjang kemeja), pola lengan yaitu (lingkar kerung lengan, lingkar ujung lengan). Penyesuaian adalah proses, cara, perbuatan menyesuaikan, sedangkan kesesuaian adalah kecocokan, keselarasan. Kesesuaian pola kemeja pria sistem Aldrich terhadap pria bertubuh ideal Indonesia didapat dengan persentase 94\%.

\section{KESIMPULA DAN SARAN}

\section{Kesimpulan}

Terdapat beberapa tahapan dalam kesesuaian pola kemeja pria sistem Aldrich terhadap pria bertubuh ideal Indonesia. Diantaranya : sesuaikan terlebih dahulu tubuh model dengan rumus badan ideal, kemudian mengambil ukuran badan sesuai dengan sistem Aldrich, memperhatikan langkah-langkah dalam pembuatan pola, melakukan fitting terhadap model, agar didapat bentuk pola yang sesuai dengan tubuh ideal pria Indonesia.

Berdasarkan hasil olah data pada fitting 1 didapatkan kesimpulan hasil analisis yang ditinjau dari modus, median, dan persentase, jawaban masing-masing panelis yang telah dilakukan pada fitting 1:

Sangat sesuai (SS) terdapat 2 item dengan dinilai sangat sesuai pada pola kemeja sistem Aldrich terhadap pria bertubuh ideal Indonesia, yaitu letak kerah pada lingkar leher, dan ketepatan pola kerah.

Sesuai (S) terdapat 9 item dengan dinilai sesuai pada pola kemeja sistem Aldrich terhadap pria bertubuh ideal di Indonesia, yaitu : panjang punggung, tinggi ketiak, letak kantong kemeja, lingkar kerung lengan, garis tengah lengan, panjang lengan, ukuran manset, lebar manset, panjang belahan manset.

Kurang sesuai (KS) terdapat 5 item dengan dinilai kurang sesuai pada pola kemeja sistem Aldrich terhadap pria bertubuh ideal di Indonesia, yaitu : Lingkar ujung lengan, lingkar kerung lengan, lebar punggung, lingkar dada, panjang kemeja.

Tidak sesuai (TS) belum terdapat item dengan dinilai kurang sesuai pada pola kemeja sistem Aldrich terhadap pria bertubuh ideal di Indonesia.
Gorga Jurnal Seni Rupa

Volume 08 Nomor 01 Januari-Juni 2019

p-ISSN: 2301-5942 | e-ISSN: 2580-2380

Berdasarkan hasil olah data pada fitting 2

Berdasarkan hasil analisis yang ditinjau dari modus, median, dan persentase jawaban dari masing-masing panelis yang telah dilakukan pada fitting II pada kategori sangat sesuai (SS) terdapat pada seluruh item, tidak terdapat hasil jawaban kurang sesuai dan tidak sesuai, dengan hasil modus 4, median 4, dan persentase $94 \%$. Untuk itu hasil analisis data pada fitting II dapat di kelompokkan dalam kategori sangat tinggi/ sangat sesuai pada pria bertubuh ideal di Indonesia.

\section{Saran}

Berdasarkan hasil penelitian yang telah disimpulkan tersebut, maka peneliti memberikan saran sebagai berikut:

Bagi mahasiswa

Mahasiswa yang akan memakai sistem pola Aldrich diharapkan memperhatikan langkahlangkah dalam pengambilan ukuran dan pembuatan pola kemeja, karena akan mempengaruhi hasil kemeja yang dibuat. Sebagai referensi dalam pembuatan busana pria, khususnya kemeja. Diharapkan ada penelitian lanjutan dengan berbagai bentuk tubuh pria Indonesia.

Bagi dosen

Bagi dosen diharapkan bisa menerapkan pola kemeja pria sistem Aldrich dalam mata kuliah busana pria, Sebagai rujukan dalam pembuatan bahan ajar.

\section{DAFTAR RUJUKAN}

Aldrich, Winifred. (2015). Metric Pattern Cutting For Men's Wear. Jakarta: PT BPK Gunung Mulia.

Alwi, Hasan . (2008). Kamus Besar Bahasa Indonesia. Jakarta: PT Gramedia Pustaka Utama.

Arikunto, Suharsimi. (2010). Prosedur Penelitian Edisi Revisi. Jakarta: PT Rineka Cipta.

Ernawati,dkk. (2008). Tata Busana Jilid 2. Jakarta: Direktorat Pembinaan Sekolah Menengah Kejuruan.

Kompas. (2003). Tinggi Rata-rata Pria Inggris dalam Urnal Elife. Diunduh pada 15 Desember 2018. [Online]. Di www.kompas.com.

Poespo, Goet. (2005). Dinamika Busana Pria. Yogyakarta: Kanisius.

Pratiwi, Djati. (2001). Pola Dasar dan Pecah Pola Busana . Yogyakarta: Pustaka Pelajar.

Soekarno. (2002). Buku Penuntun Pola Busana Tingkat Dasar. Jakarta: Gramedia Pustaka Indonesia.

Sudjiono, Anas. (2011). Pengantar Statistik Pendidikan. Jakarta: Rajawali Press.

Sugiyono. (2009). Statistika Untuk Penelitian. Bandung: Alfabeta. 
Surya, Djaja. (2010). Rata-rata Tinggi Pria Indonesia,. Diunduh pada 25 Maret 2018. [Online]. Di www. Survei tinggi tubuh orang Indonesia.

Thomas. (2008). Sistem Pengukuran Berat Badan dan Tinggi Badan Menggunakan Mikrokontelar AT89531, 10(2), 5-9.

Wening, Sri. (2013). Modul Busana Pria. Yogyakarta: Fakultas Teknik Universitas Negeri Yogyakarta.

Yasnidawati. (2012). Busana Tailoring. Padang: Universitas Negeri Padang. 